\title{
The Impact of Scaffolded Writing on Activating Passive Vocabularies of Iranian Upper- intermediate EFL Learners
}

\author{
Mansoor Fahim \\ Faculty of Foreign Languages, Islamic Azad University, Central Tehran Branch, Iran \\ Bahareh Jouybar \\ Faculty of Foreign Languages, Islamic Azad University, South Tehran Branch, Iran
}

\begin{abstract}
This case study explores the implementation of scaffolded writing in activating passive vocabularies in Iranian upper-intermediate EFL learners. PET and Vocabulary Size Test are utilized to select 64 participants among 95 EFL learners. Then according to their correspondingly similar vocabulary scores, the participants are divided into Experimental and Control groups. Scaffolded writing was an add-on component which was given as a treatment to the experimental group. To measure the vocabulary used in the compositions of Iranian students, the RANGE software is used. Results indicated that after scaffolded writing there was a higher usage of advanced vocabulary use in paragraph writing with a proportion of $5.4 \%$ in the reservoir of passive vocabulary into active vocabulary. The research implies that since the students get involved in cooperative activities and they share their ideas, there is a possibility for activating less frequent words. The positive effect of scaffolded writing boosts active vocabulary development. Both EFF/ESL teachers and students can benefit from the findings of this study.
\end{abstract}

Index Terms-Scaffolded writing, passive vocabularies, Iranian EFL learners

\section{INTRODUCTION}

The concept of scaffolding is linked to the work of the Russian social psychologist Lev Vygotsky. He coined the term Zone of Proximal Development (ZPD) to make a difference between the actual developmental level by individual problem-solving and the level of potential development enhanced by problem-solving with more capable peers.

According to Hartman (2002), scaffolding theory was first introduced in the late 1950s by Bruner. It was used to describe oral language acquisition of learners assisted by their parents when learning to speak. Cazden (1983, p.6) defined a scaffold as a impermanent framework for construction in progress. Parents may know how to help and scaffold their children while negotiating meaning. Scaffold may occur when child may not be able to articulate or search learning by himself.

In terms of vocabulary, researchers agree, based on Hatch and Brown (1995) that vocabulary learning is of high importance when learning a language. The more words we try to learn, the more ability we will have to deal with what we hear and read; the better we will be able to express ourselves. We first choose the words and then we have to determine how we are going to learn them. These vocabularies are divided into two groups; passive and active vocabulary.

\section{REVIEW OF THE RELATED LITERATURE}

\section{A. Scaffolding}

Lev Vygotsky's sociocultural theory and his concept of ZPD is the originator of scaffolding strategy. The zone of proximal development is the distance between what children can do by themselves and the next learning that they can be helped to achieve with competent assistance (Raymond, 2000, p.176). The scaffolding strategy, as Chang, Sung and Chen (2002) assert allows for individualized cooperation and the activities provided in scaffolding instruction, according to Olson and Platt (2000), are a little beyond the level of learner's individual capability. Therefore, in order to help learners through the ZPD, as Bransford, Brown, and Cocking (2000) assert, the more capable others provide the scaffolds so that the learners can accomplish the tasks they could otherwise not complete.

\section{B. Scaffolded Writing}

Teachers at all levels in recent years of instruction have become very much interested in knowing how they can back up their students in learning and using different forms of written language. Scaffolding is one useful metaphor for this support. Scaffolded Writing is a actually originated from the work of Elkonin and Galperin, who were two of 
Vygotsky's students and colleagues. Elkonin and Galperin developed this technique in 1994 (cited in Bodrova \& Leong, 1996). It sure needs the use of Vygotskian three strategies: materialization, private speech and shared activity.

To Vygotsky, based on Bodrova and Leong (1996), an effective intervention needs support for children within their Zone of Proximal Development. Several studies have used private speech and materialization to scaffold learning in Russia (Venger 1986). For example, Elkonin (1971) applied the two strategies in the well-known study of phonemic awareness. The preschool and kindergarten children who took part in his program learned to read faster than the control group and gained better marks in measures of metalinguisitc awareness. Teachers must help learners develop strategies if scaffolding is to be successful.

\section{Vocabulary}

For sure, learning vocabulary is the necessary condition of learning a second language; however in this process a learner never completes vocabulary acquisition. The acquisition of new vocabulary is a continued process in both one's native language or a second language. According to Nation (2003), vocabulary is commonly delineated as all the words known and used by a single person. However, this definition may not take into account a range of issues involved in knowing a word.

According to Hatch and Brown (1995), some methods can assist learners to acquire new vocabularies including following steps:

1. Facing new words

2. Getting the form of the word

3. Getting the meaning of the word

4. Consolidating word form and meaning in memory

5. Using the word (passive/active vocabulary)

The source of vocabulary for a person is the set of familiar words within a language. The repertoire of vocabulary generally develops with age, and is a useful key tool for communication and acquiring any sort of knowledge. Based on Lieb (2006), one of the biggest challenges in learning a second language is acquiring a comprehensive vocabulary.

\section{Statement of the Problem}

Most of upper-intermediate EFL learners are not able to use the vocabularies that have been learned; though, they have high knowledge of vocabularies, they only use simple words in their speaking; and many of their vocabularies are passive. In learning English language, all four skills should be taken into account, but speaking has crucial role in terms of acceptable communication, so learners can improve their speaking ability through using various vocabularies. But unfortunately, instructors do not encourage EFL learners to use different vocabularies in their speaking; therefore, learners just use simple and common words and do not bother themselves to activate passive words. It is hoped that this study helps Iranian upper-intermediate EFL learners use passive words in their speaking through scaffolded writing.

\section{E. Research Question}

Does scaffolded writing have a positive impact on activating passive vocabularies of Iranian upper-intermediate EFL learners?

\section{F. Research Null Hypothesis}

H0: Scaffolded writing does not have a positive impact on activating passive vocabularies of Iranian upperintermediate EFL learners.

\section{MethodOLOGY}

\section{A. Participants}

First, 95 students were chosen from Goldis Institute in Tehran, ranging from 18 to 28at upper - intermediate level. According to the results of the homogeneity test, 82 students were selected. The vocabulary size test (Nation \& Beglar, 2007) was administered to all the participants at the beginning of the course in order to determine students' proficiency level in terms of receptive/passive/recognition vocabulary knowledge. Finally, a total of 64 students were chosen.

\section{B. Instruments}

In this research, following instruments were provided:

- Dictionary: The students were provided with bilingual dictionary in order to remove their problems.

- Cross-word puzzle: to introduce the term cooperative,

- Information gap activities: Participants in the experimental group were provided with some activities including blanks in order to fill the gaps cooperatively. Students in control group did information gap activities individually.

- Nation test: The Vocabulary Size Test used for measuring controlled active and passive vocabulary size

- Lexical Frequency Profile (LFP): Used for showing the relationship between learners' vocabulary size and the richness of vocabulary in the production of language.

\section{Procedures}


The Vocabulary Size Test was given to 82 students at the beginning of the course in order to determine students' proficiency level considerin active/passive vocabulary knowledge. The test was developed originally by Nation and Beglar (2007).

After this test, the students' compositions were grouped based on their correspondingly similar vocabulary scores across two groups. As an example, if four students had test scores 3500 (=35 out of 140 test items being correct * 100) they were grouped into two groups including experimental and control group. Each group consists of two students and one of the students was discarded from the research. In this case, both groups could remain intact and comparisons would be done more easily. Any difference growing from the explanatory variable would be more easily observed. In the end, a total of 32 pairs of students from two groups were selected.

In the first two sessions, the researcher presented some writing methods in both control and experimental groups. The class was divided into four rhetorical styles of paragraphs: comparison, contrast, description, and narration and also cause-and-effect. In the first 2-hour session for a writing theme, the lectures of the content in the textbook proceeded in order to present and discuss methods, patterns of organizations and various rhetorical styles such as sequential order in narrative paragraph writing, point-by-point or block method in comparison \& contrast, focus-on-causes and focus-oneffects methods. Tasks and exercises of the class for each writing unit concentrated on developing supporting ideas, formulating a topic sentence, building better sentences and bringing the paragraph to a logical conclusion. In the next session for a writing unit, the researcher tried to make students aware of cohesion, coherence and keeping their writing focused.

\section{RESULTS AND DisCUSSIONS}

\section{A. Descriptive Statistics}

Table 1 below shows the means of vocabulary size test and the standard deviations for all 32 pairs of upperintermediate students chosen based on their similar scores on the Vocabulary Size Test (32 students from the scaffolded writing classes and 32 from the non- scaffolded writing classes).

The students' vocabulary scores were further classified into three levels: the vocabulary size above 5000 words, of $3500-5000$ words and below 3500 words. The number of the correct test items ( $n=140$ vocabulary items) multiplied by 100 equals the vocabulary size.

TABLE 1:

UPPER INTERMEDIATE LEARNERS' PASSIVE VOCABULARY SIZE MEASURED BY THE VOCABULARY SIZE TEST

\begin{tabular}{|l|l|l|l|}
\hline Vocabulary size & No. of Students & Mean & SD \\
\hline above 5100 & 12 & $\begin{array}{l}5642 \\
\text { Min=5100;max=6800 }\end{array}$ & 529.44 \\
\hline $3600-5000$ & 32 & $\begin{array}{l}4156 \\
\text { Min=3600;max=4900 }\end{array}$ & 409.51 \\
\hline below 3500 & 20 & $\begin{array}{l}3185 \\
\text { Min=2900;max=3500 }\end{array}$ & 203.33 \\
\hline & & & \\
\hline
\end{tabular}

The vocabulary size for 32 out of 64 was at the range of 3500-5000 words with the mean of 4156 and SD of 409.51 . As to the 20 low-proficiency students' vocabulary scores, nothing was found to be below 2000 words. Nation (1990) asserts that the 2000-word level includes the very high-frequency words that is necessary for students when reading texts. In this regard, these students had gained the beginning for the minimum vocabulary requirement.

\section{B. Analyzing the Research Question}

Research Question: Does scaffolded writing have a positive impact on activating passive vocabularies in Iranian upper-intermediate EFL learners?

To activate students' passive vocabulary in experimental group, scaffolded writing served as an explanatory variable. The researcher chose 4 topics (Food, marriage, education, and transportation) and asked the students to write on those topics during 20 sessions. As it was mentioned, in experimental group, the researcher used scaffolded writing activities, whereas the students in control group were not provided by any scaffolded activities.

At the end of each 5 sessions that one topic was covered, in both groups, each student was asked to write one writing about that topic individually. the researcher followed this procedure for 4 topics. The level of used vocabularies in students' paragraph writings was analyzed by RANGE program. Two kinds of LFP were modified into a more condensed version, consisting of the percentage of the basic 2000 words and the percentage of vocabulary use beyond 2000 due to the limited vocabulary of EFL students named LFP ratio. Then the researcher compared the level of vocabularies (LFP ratio) in two groups to determine activating passive vocabularies. Using more advanced vocabularies (beyond 2000) in students' paragraph writing indicated more active vocabularies.

The following is one example for one paragraph writing on the topic entitled "The disadvantages of fast food" from a student in the non-Scaffolded writing class, whose vocabulary size was 4100 words. His LFP ratio $(92.6 \%-7.4 \%)=(\%$ below 2000 — \% above 2000 in word families) indicates a low percentage of higher-level vocabulary use. 
Nowadays there is a growing demand for fast food due to several reasons. What may cross every individual's mind is what pros of fast food are.

One of the most important aspects of having fast food is its quickness in preparation. Sometimes it's of more importance for the consumers to just have a quick meal and fast food is the best option for this need, another upside of fast food which can be noted is its popular taste among young people.

Despite its pros there are some to it. First and foremost it has got a lot of amount of high fat, which will be converted to fat after its entrance and will not do a lot of goods to body.

Furthermore, it does not contain any essential vitamins for body.

To sum up, despite its quickness for preparation, fast food could not be considered a healthy for intake body and it's better to have other foods as the mail meals.

TABLE 2:

THE VOCABULARY LEVELS OF THE COMPOSITION ENTITLED 'THE DISADVANTAGES OF FAST FOOD' IN NON-SCAFFOLDED WRITING CLASS

\begin{tabular}{|l|l|l|l|l|l|}
\hline BNC & Tokens/ \% & Types/ \% & \# of word families & Headword \\
\hline 1st - 2nd 1000 & $157 / 95.71$ & $88 / 92.63$ & 75 & LFP ratio \\
\hline 3rd 1000 & $1 / 0.61$ & $1 / 1.05$ & 1 & CONVERTED \\
\hline 4th 1000 & $3 / 1.84$ & $3 / 3.16$ & 3 & below 2000-\% \\
& & & & $\begin{array}{l}\text { FOREMOST, } \\
\text { IMPORTANCE, } \\
\text { families })\end{array}$ \\
\hline 5th 1000 & $1 / 0.61$ & $1 / 1.05$ & 1 & FITAMINS \\
\hline 6th 1000 & $1 / 0.61$ & $1 / 1.05$ & 1 & INTAKE & \\
\hline Total & $163 / 100 \%$ & $94 / 100 \%$ & 81 & \\
\hline
\end{tabular}

Table 2 above shows the vocabulary levels of the related paragraph with the scale of the BNC 14,000 high-frequency word lists. Participants' 163-word composition included using 81 word families. One of them was near the 6th 1000 word frequency level, another in the 5th 1000 level, three in the 4th 1000 (foremost, importance and vitamins), and one in the 3th (converted). The high 2000 words with the BNC scale were considered frequent vocabulary while the words above 2000 were seen as less frequent vocabulary. The student's lexical frequency profile (LFP) in a modified version was $92.6 \%-7.4 \%$. That is, $92.6 \%$ of the entire word families in their paragraph writing belonged to the basic 2000 word families. (92.6\% equaled to 75 word families in the first and second 1000 frequent words divided by the total 82 word families.), versus $7.4 \%$ for the use of vocabulary beyond the 2000 frequent words. Comparing their receptive/passive vocabulary size, i.e. 4100 words, the LFP ratios clearly show that participant's productive proficiency had not come to a standstill regarding advanced/less frequent vocabulary use.

Contrary to this, here is an example from a student who took part in the scaffolded writing with a vocabulary of 4100 words on the Vocabulary Size Test (Same topic: The disadvantages of fast food).

In our time life has became very busy that sometimes we even don't have enough time to concentrate what we are eating. many people eat in fast food restaurants the food is delicious bad it has bad effects on our body because the oil in the restaurants maybe be fried for several times and make cancer. Another disadvantage is using sausage and some other meats that last long and these kinds of meats can cause disease for stomach. Another thing is vegetables sometimes fast foods don't wash them very well and can make us ill. Fast food can addict you to eat these kinds of things like pizza hamburger and... And it can waste our money too. In some cases the meat is raw because of many customers and its really dangerous. Going to fast food regularly can cause heart problem because of greasy food. The quality of materials that restaurants use is usually not good and they are cheap. Like donkey meat. The common drink in fast foods is coca that is very bad for teeth and it has a lot of sugar instead of it it's better to use mineral water. Fast food can make allergic worse. At all it's better to use healthy and home food but if rarely use fast food it is not too bad!

TABLE 3:

THE VOCABULARY LEVELS OF THE COMPOSITION ENTITLED “THE DISADVANTAGES OF FAST FOOD” AFTER PARTICIPATING IN SCAFFOLDED WRITING

\begin{tabular}{|l|l|l|l|l|l|}
\hline BNC & Tokens/ \% & Types/ \% & \# of word families & Headword \\
\hline 1st -2nd 1000 & $207 / 92.41$ & $106 / 87.61$ & 89 & $\begin{array}{l}85.6 \%-14.4 \% \\
(\% \text { below 2000-\% } \\
\text { above 2000 in word } \\
\text { families })\end{array}$ \\
\hline 3rd 1000 & $9 / 4.02$ & $7 / 5.79$ & 7 & $\begin{array}{l}\text { ADDICT, CANCER, } \\
\text { FRIED, RAW, } \\
\text { RESTAURANTS, } \\
\text { SAUSAGE, } \\
\text { STOMACH }\end{array}$ \\
\hline 4th 1000 & & & & ALLERGIC, \\
& & & MINERAL \\
\hline 5th 1000 & $2 / 0.89$ & $2 / 1.65$ & 2 & $\begin{array}{l}\text { COCA, DONKEY, } \\
\text { GREASY, } \\
\text { HAMBURGER }\end{array}$ \\
\hline 6th 1000 & $4 / 1.79$ & $4 / 3.31$ & 4 & DELICIOUS, PIZZA \\
\hline Total & & & & \\
\hline
\end{tabular}


After participating in scaffolded writing class, the student with a 4100 -word vocabulary indeed performed better in using more sophisticated vocabulary (see Table 3, altogether fifteen words being sporadically between the 3rd-6th word levels; the percentage of advanced vocabulary use $=14.4 \%$ ), compared with the student of equal proficiency from the other class without scaffolded writing (altogether six words being sporadically between the 3rd-6th word levels; the usage rate of advanced vocabulary $=7.4 \%$ ).

The mean of LFP ratio is analyzed according to table 4 (appendix A) and table 5 (appendix B) for all of students in two groups. In the analysis, an independent $t$ - test was used to compare the values of the means for two samples and check to see if it was likely that the samples were from populations with different mean values. The samples are independent of each other in that they are separate samples with different sets of individual subjects. Table 6 shows the group statistics and independent t-test for the LFP.

TABLE6.

GROUP STATISTICS

\begin{tabular}{|c|c|c|c|c|c|}
\hline \multicolumn{2}{|c|}{ Scaffolded writing } & $\mathrm{N}$ & Mean & Std. Deviation & Std. Error Mean \\
\hline \multirow[t]{2}{*}{ LFP } & NSW & 32 & 9.1859 & 2.38932 & .42238 \\
\hline & SW & 32 & 14.5875 & 2.21589 & .39172 \\
\hline
\end{tabular}

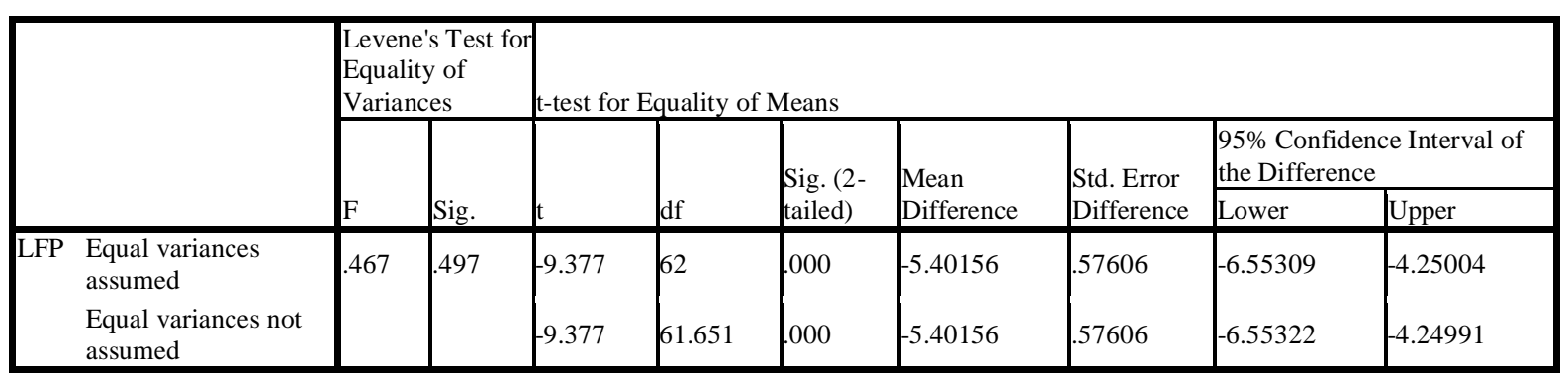

Table 8 below shows the LFP ratios for the two classes with and without the treatment of scaffolded writing on the given topics. The results showed a clear difference in the percentage of more frequent and less frequent vocabulary use for the two classes (mean LFP ratio for class without scaffolded writing $=90.8 \%-9.2 \%$ versus mean LFP ratio for class with scaffolded writing $=85.4 \%-14.6 \%$ ). The inferiority of the non- scaffolded writing class to the scaffolded writing class in producing more advanced words was statistically obvious (mean $=9.2 \%$ for class without scaffolded writing versus mean $=14.6 \%$ for the scaffolded writing class; $\mathrm{t}=9.373$, sig. $=0.000<0.01$ ). This verified that scaffolded writing can activate passive vocabularies in Iranian EFL learners.

TABLE 8

TWO CLASSES' MEAN LFP RATIOS FOR THE FOUR COMPOSITIONS AS A WHOLE

\begin{tabular}{|l|l|l|}
\hline & $\begin{array}{l}\text { Class without scaffolded writing } \\
(\mathrm{n}=32)\end{array}$ & Class with scaffolded writing $(\mathrm{n}=32)$ \\
\hline Mean LFP ratios $(\%$ of the word & mean=90.8\%-9.2\% & mean=85.4\%-14.6\% \\
families used below the 2000-word & $\mathrm{SD}=2.4 \%$ & $\mathrm{SD}=2.2 \%$ \\
level-\% above 2000) & $97.6 \%-\mathbf{2 . 4 \%}$ min. & $94.8 \%-\mathbf{5 . 2 \%}$ min. \\
& $81.1 \%-\mathbf{1 8 . 9 \%}$ max. & $76.9 \%-\mathbf{2 3 . 1 \%}$ max. \\
\hline Independent-samples t test & $\mathrm{t}(\mathrm{df} 62)=9.377$, Sig. $(2$-tailed $)=0.000<0.01$ \\
\hline
\end{tabular}

\section{Discussions}

In reply to research question, does scaffolded writing have a positive impact on activating passive vocabularies of Iranian upper-intermediate EFL learners? A direct deduction of 9.2\% from $14.6 \%$ was carried out. The result showed an increased productivity of recognition vocabulary, tantamount to an increase of $5.4 \%$ in turning higher-level vocabulary in the source of passive vocabulary and turning it into active vocabulary. One may expand his/her normal range of active vocabulary by voluntary attempts to use higher-level vocabulary and through multiple scaffolded methods to English. These efforts to use higher-level vocabulary showed higher usage of vocabulary in writing. Also, as a result of richer advanced vocabulary, it may contribute to overall improvement in writing ability.

In data analysis considering the variables studied in this research, the following results have been gained. A substantial difference was observed between the arithmetic means of the groups' LFP ratio proving the strength of the experimental group. With $95 \%$ degree of confidence $(\mathrm{p}<0.05)$ there is important difference between the two groups. It has been observed that the $\mathrm{p}$-value in two independent t-test was higher than 0,05 . Consequently, the hypothesis of the research, that activating passive vocabularies of Iranian upper intermediate EFL learners through scaffolded writing is a very effective technique, has been supported with the results.

Scaffolding instruction as a teaching strategy can remove some teaching problems (Vygotsky, 1976). According to similar international studies the previous findings showed scaffolded activities can have effect on writing (Larkin, 2002), 
phonemic awareness (Elkonin, 1971), self regulation (McCarthy, 1992) and PBL (Problem Based Learning). However, in this thesis the impact on activating passive vocabularies had been confirmed.

\section{CONCLUSIONS AND IMPLICATIONS}

In this study the researcher tried to find answer to the following research question: Does scaffolded writing have a positive impact on activating passive vocabularies of Iranian upper-intermediate EFL learners?

The positive outcome showed an enhanced productivity of recognition vocabulary in changing state of higher-level vocabulary in the source of passive vocabulary into active vocabulary. Learners may enlarge their common load of active vocabulary by trying to use higher-level vocabulary through multiple scaffolded methods in learning English language. The increased attempts on the part of participants in using higher-level vocabulary could be a signal for higher awareness of vocabulary use in writing contributing to general improvement in writing quality as an effect of richer advanced vocabulary. A meaningful difference was found between the arithmetic means in LFP ratio of the experimental group, confirming that there existed substantial difference between the two groups.

As stated by Vygotsky (1976), scaffolding instruction as a teaching strategy can remove some teaching problems, which in this case the writing was under consideration. Findings of practitioners of TEFL also support the researcher's claim that scaffolded activities can have positive effect on improving students writing (Larkin, 2002; Hyland, 2003).

Another researcher's purpose for conducting this research was to motivate herself to use other techniques of teaching vocabularies to students for further researches. On the one hand, being aware of many hours spent on using different techniques in the process of vocabulary teaching and adding or modifying existing techniques may demotivate the researchers from further work in this area. On the other hand, the surprising results of the research within the experimental group, as well as many positive remarks given by them (participants), do encourage the researcher to further develop and modify the application. 
APPENDIX A

TABLE 4.

LFP RATIO IN NON-SCAFFOLDED WRITING CLASS

\begin{tabular}{|c|c|c|c|c|c|c|c|c|c|c|c|}
\hline \multicolumn{12}{|c|}{ Non Scaffolded writing class } \\
\hline \multirow[b]{2}{*}{ No } & \multirow{2}{*}{$\begin{array}{l}\text { V.S.T } \\
\text { score }\end{array}$} & \multicolumn{2}{|c|}{ LFP Ratio Topic 1} & \multicolumn{2}{|c|}{ LFP Ratio Topic 2} & \multicolumn{2}{|c|}{ LFP Ratio Topic 3} & \multicolumn{2}{|c|}{ LFP Ratio Topic 4} & \multicolumn{2}{|c|}{ Mean of LFP Ratio } \\
\hline & & $\begin{array}{l}\text { below } \\
2000\end{array}$ & $\begin{array}{l}\text { above } \\
2000\end{array}$ & $\begin{array}{l}\text { below } \\
2000\end{array}$ & $\begin{array}{l}\text { above } \\
2000\end{array}$ & $\begin{array}{l}\text { below } \\
2000\end{array}$ & $\begin{array}{l}\text { above } \\
2000\end{array}$ & $\begin{array}{l}\text { below } \\
2000\end{array}$ & $\begin{array}{l}\text { above } \\
2000\end{array}$ & $\begin{array}{l}\text { below } \\
2000\end{array}$ & $\begin{array}{l}\text { above } \\
2000\end{array}$ \\
\hline 1 & 2900 & 92.7 & 7.3 & 97.6 & 2.4 & 90.5 & 9.5 & 94 & 6 & 93.7 & 6.3 \\
\hline 2 & 3500 & 88.3 & 11.7 & 92.2 & 7.8 & 94 & 6 & 93.9 & 6.1 & 92.1 & 7.9 \\
\hline 3 & 3000 & 97 & 3 & 92.3 & 7.7 & 90.3 & 9.7 & 93.6 & 6.4 & 93.3 & 6.7 \\
\hline 4 & 3300 & 90.4 & 9.6 & 92.3 & 7.7 & 89.6 & 10.4 & 90.9 & 9.1 & 90.8 & 9.2 \\
\hline 5 & 3000 & 94 & 6 & 92.6 & 7.4 & 91 & 9 & 91.5 & 8.5 & 92.3 & 7.725 \\
\hline 6 & 3300 & 92.4 & $\overline{7.6}$ & 92.7 & $\overline{7.3}$ & $\overline{92.6}$ & $\overline{7.4}$ & 91.2 & 8.8 & 92.2 & 7.775 \\
\hline 7 & 3000 & 94 & 6 & 90.5 & $\overline{9.5}$ & 97 & 3 & 93.5 & 6.5 & 93.8 & 6.25 \\
\hline 8 & 3200 & 89.6 & 10.4 & 94.9 & 5.1 & 93.4 & 6.6 & 95.9 & 4.1 & 93.5 & 6.55 \\
\hline 9 & 3100 & 89.8 & 10.2 & 95.8 & 4.2 & 94.3 & 5.7 & 91.5 & 8.5 & 92.9 & 7.15 \\
\hline 10 & 3400 & 95.2 & 4.8 & 92 & 8 & 92.7 & 7.3 & 92.2 & 7.8 & 93.0 & 6.975 \\
\hline 11 & 4100 & $\overline{92.6}$ & $\overline{7.4}$ & 91 & 9 & 94 & 6 & 89.2 & 10.8 & 91.7 & 8.3 \\
\hline 12 & 4200 & 92.6 & 7.4 & 93.6 & 6.4 & 90.2 & $\overline{9.8}$ & 88.6 & 11.4 & 91.3 & 8.75 \\
\hline 13 & 3900 & 92.2 & $\overline{7.8}$ & 92.4 & $\overline{7.6}$ & 92 & 8 & 88.8 & $\overline{11.2}$ & 91.4 & 8.65 \\
\hline 14 & 3700 & 93.6 & 6.4 & 91.3 & 8.7 & 91.6 & 8.4 & 93.3 & 6.7 & 92.5 & 7.55 \\
\hline 15 & 3800 & 88.4 & 11.6 & 89.3 & 10.7 & 91.9 & 8.1 & 93.2 & 6.8 & 90.7 & 9.3 \\
\hline 16 & 4600 & 88.8 & 11.2 & 86.8 & 13.2 & 91.7 & 8.3 & 89.5 & 10.5 & 89.2 & 10.8 \\
\hline 17 & 3800 & 90.4 & 9.6 & 93.9 & 6.1 & 90.3 & 9.7 & 92.4 & 7.6 & 91.8 & 8.25 \\
\hline 18 & 4600 & 93.8 & 6.2 & 87 & 13 & 88.4 & 11.6 & 90.7 & 9.3 & 90.0 & 10.03 \\
\hline 19 & 3600 & 88.8 & 11.2 & 95.7 & 4.3 & 95.7 & 4.3 & 92.9 & 7.1 & 93.3 & 6.725 \\
\hline 20 & 3700 & 93.6 & 6.4 & 94.8 & 5.2 & 92.2 & 7.8 & 92.5 & 7.5 & 93.3 & 6.725 \\
\hline 21 & 4900 & 90.2 & 9.8 & 86.5 & 13.5 & 88.8 & 11.2 & 89.9 & 10.1 & 88.9 & 11.15 \\
\hline 22 & 4500 & 90 & 10 & 92.2 & 7.8 & 88 & 12 & 93.3 & 6.7 & 90.9 & 9.125 \\
\hline 23 & 4300 & 93.4 & 6.6 & 93.7 & 6.3 & 92.4 & 7.6 & 94.1 & 5.9 & 93.4 & 6.6 \\
\hline 24 & 4000 & 91 & 9 & 91.9 & 8.1 & 89.5 & 10.5 & 88.7 & 11.3 & 90.3 & 9.725 \\
\hline 25 & 4800 & 86.4 & 13.6 & 86.6 & 13.4 & 87.5 & 12.5 & 91.3 & 8.7 & 88.0 & 12.05 \\
\hline 26 & 4000 & 92 & 8 & 88.6 & 11.4 & 88.3 & 11.7 & 88.9 & 11.1 & 89.5 & 10.55 \\
\hline 27 & 6800 & 85.4 & 14.6 & 84.5 & 15.5 & 88.4 & 11.6 & 84.7 & 15.3 & 85.8 & 14.25 \\
\hline 28 & 5100 & 89.8 & 10.2 & 81.3 & 18.7 & 86.1 & 13.9 & 86.9 & 13.1 & 86.0 & 13.98 \\
\hline 29 & 5100 & 87.8 & 12.2 & 91.5 & 8.5 & 89.7 & 10.3 & 87.6 & 12.4 & 89.2 & 10.85 \\
\hline 30 & 5600 & 91.8 & 8.2 & 86.5 & 13.5 & 87.3 & 12.7 & 84.8 & 15.2 & 87.6 & 12.4 \\
\hline 31 & 5500 & 90 & 10 & 86.5 & 13.5 & 91.2 & 8.8 & 85.5 & 14.5 & 88.3 & 11.7 \\
\hline \multirow[t]{5}{*}{32} & 5900 & 81.1 & 18.9 & 88.5 & 11.5 & 90.1 & 9.9 & 88.4 & 11.6 & 87.0 & 12.98 \\
\hline & Ave & 90.8 & 9.2 & 90.8 & 9.2 & 91.0 & 9.0 & 90.7 & 9.3 & 90.8 & 9.2 \\
\hline & SD & 3.1 & 3.1 & 3.7 & 3.7 & 2.5 & 2.5 & 2.9 & 2.9 & 2.3 & 2.3 \\
\hline & Min & 81.1 & 3.0 & 81.3 & 2.4 & 86.1 & 3.0 & 84.7 & 4.1 & 81.1 & 2.4 \\
\hline & Max & 97.0 & 18.9 & 97.6 & 18.7 & 97.0 & 13.9 & 95.9 & 15.3 & 97.6 & 18.9 \\
\hline
\end{tabular}


APPENDIX B

TABLE 5

LFP RATIO IN SCAFFOLDED WRITING CLASS

\begin{tabular}{|c|c|c|c|c|c|c|c|c|c|c|c|}
\hline \multicolumn{12}{|c|}{ Scaffolded writing class } \\
\hline \multirow[b]{2}{*}{ No } & \multirow{2}{*}{$\begin{array}{l}\text { V.S.T } \\
\text { score }\end{array}$} & \multicolumn{2}{|c|}{ LFP Ratio Topic 1} & \multicolumn{2}{|c|}{ LFP Ratio Topic 2} & \multicolumn{2}{|c|}{ LFP Ratio Topic 3} & \multicolumn{2}{|c|}{ LFP Ratio Topic 4} & \multicolumn{2}{|c|}{ Mean of LFP Ratio } \\
\hline & & $\begin{array}{l}\text { below } \\
2000\end{array}$ & $\begin{array}{l}\text { above } \\
2000\end{array}$ & $\begin{array}{l}\text { below } \\
2000\end{array}$ & $\begin{array}{l}\text { above } \\
2000\end{array}$ & $\begin{array}{l}\text { below } \\
2000\end{array}$ & $\begin{array}{l}\text { above } \\
2000\end{array}$ & $\begin{array}{l}\text { below } \\
2000\end{array}$ & $\begin{array}{l}\text { above } \\
2000\end{array}$ & $\begin{array}{l}\text { below } \\
2000\end{array}$ & $\begin{array}{l}\text { above } \\
2000\end{array}$ \\
\hline 1 & 3300 & 88.2 & 11.8 & 82.4 & 17.6 & 86.1 & 13.9 & 85.1 & 14.9 & 85.5 & 14.6 \\
\hline 2 & 3500 & 83.3 & 16.7 & 89 & 11 & 90 & 10 & 85.5 & 14.5 & 87.0 & 13.1 \\
\hline 3 & 3000 & 90.2 & 9.8 & 81.5 & 18.5 & 89.9 & 10.1 & 92.2 & 7.8 & 88.5 & 11.6 \\
\hline 4 & 3200 & 92.1 & 7.9 & 91.7 & 8.3 & 86 & 14 & 91.5 & 8.5 & 90.3 & 9.7 \\
\hline 5 & 3000 & 93.4 & 6.6 & 83.4 & 16.6 & 89.5 & 10.5 & 86.4 & 13.6 & 88.2 & 11.8 \\
\hline 6 & 3300 & 83.2 & 16.8 & 93.6 & 6.4 & 86.1 & 13.9 & 86.1 & 13.9 & 87.3 & 12.8 \\
\hline 7 & 3400 & 88.4 & 11.6 & 82.7 & 17.3 & 85.1 & 14.9 & 89.4 & 10.6 & 86.4 & 13.6 \\
\hline 8 & 3100 & 81.3 & 18.7 & 87.7 & 12.3 & 83 & 17 & 92.3 & 7.7 & 86.1 & 13.9 \\
\hline 9 & 3000 & 82.7 & 17.3 & 81.2 & 18.8 & 87.5 & 12.5 & 91.6 & 8.4 & 85.8 & 14.3 \\
\hline 10 & 3000 & 85.6 & 14.4 & 83.9 & 16.1 & 94.8 & 5.2 & 94.4 & 5.6 & 89.7 & 10.3 \\
\hline 11 & 3700 & 89.5 & 10.5 & 86 & 14 & 90.9 & 9.1 & 86.6 & 13.4 & 88.3 & 11.8 \\
\hline 12 & 4900 & 88.3 & 11.7 & 82.5 & 17.5 & 79.7 & 20.3 & 78 & 22 & 82.1 & 17.9 \\
\hline 13 & 4600 & 82.6 & 17.4 & 84.1 & 15.9 & 79.8 & 20.2 & 90.2 & 9.8 & 84.2 & 15.8 \\
\hline 14 & 4000 & 81.4 & 18.6 & 82.1 & 17.9 & 90.5 & 9.5 & 91.1 & 8.9 & 86.3 & 13.7 \\
\hline 15 & 4600 & 85.9 & 14.1 & 85.9 & 14.1 & 84.8 & 15.2 & 87.5 & 12.5 & 86.0 & 14.0 \\
\hline 16 & 4300 & 83.5 & 16.5 & 82.4 & 17.6 & 84.6 & 15.4 & 86.6 & 13.4 & 84.3 & 15.7 \\
\hline 17 & 3800 & 86.6 & 13.4 & 83.6 & 16.4 & 88.8 & 11.2 & 81.7 & 18.3 & 85.2 & 14.8 \\
\hline 18 & 4100 & 85.6 & 14.4 & 79.2 & 20.8 & 83.4 & 16.6 & 87.9 & 12.1 & 84.0 & 16.0 \\
\hline 19 & 3800 & 80.3 & 19.7 & 82.5 & 17.5 & 91.9 & 8.1 & 88.2 & 11.8 & 85.7 & 14.3 \\
\hline 20 & 3900 & 87.9 & 12.1 & 89.1 & 10.9 & 86.1 & 13.9 & 79.7 & 20.3 & 85.7 & 14.3 \\
\hline 21 & 4800 & 80.3 & 19.7 & 80.9 & 19.1 & 83.8 & 16.2 & 85.6 & 14.4 & 82.7 & 17.4 \\
\hline 22 & 3600 & 82.4 & 17.6 & 82.9 & 17.1 & 89.1 & 10.9 & 82.2 & 17.8 & 84.2 & 15.9 \\
\hline 23 & 4000 & 81.2 & 18.8 & 88.9 & 11.1 & 80.4 & 19.6 & 90 & 10 & 85.1 & 14.9 \\
\hline 24 & 4200 & 88.9 & 11.1 & 87.9 & 12.1 & 79.4 & 20.6 & 86.2 & 13.8 & 85.6 & 14.4 \\
\hline 25 & 4500 & 81.5 & 18.5 & 89.2 & 10.8 & 80 & 20 & 84.5 & 15.5 & 83.8 & 16.2 \\
\hline 26 & 3700 & 83.8 & 16.2 & 81.2 & 18.8 & 88.4 & 11.6 & 83.4 & 16.6 & 84.2 & 15.8 \\
\hline 27 & 5200 & 77.7 & 22.3 & 83 & 17 & 85.2 & 14.8 & 89.4 & 10.6 & 83.8 & 16.2 \\
\hline 28 & 5500 & 86.7 & 13.3 & 77.6 & 22.4 & 83.6 & 16.4 & 89.7 & 10.3 & 84.4 & 15.6 \\
\hline 29 & 5600 & 77.7 & 22.3 & 80.3 & 19.7 & 86 & 14 & 84.1 & 15.9 & 82.0 & 18.0 \\
\hline 30 & 5100 & 83.6 & 16.4 & 90.7 & 9.3 & 86.7 & 13.3 & 90.7 & 9.3 & 87.9 & 12.1 \\
\hline 31 & 6300 & 87.7 & 12.3 & 79.8 & 20.2 & 76.9 & 23.1 & 85.7 & 14.3 & 82.5 & 17.5 \\
\hline 32 & 6000 & 81.9 & 18.1 & 83.3 & 16.7 & 81.7 & 18.3 & 78.1 & 21.9 & 81.3 & 18.8 \\
\hline & Ave & 84.8 & 15.2 & 84.4 & 15.6 & 85.6 & 14.4 & 86.9 & 13.1 & 85.4 & 14.6 \\
\hline & SD & 3.9 & 3.9 & 3.9 & 3.9 & 4.2 & 4.2 & 4.1 & 4.1 & 2.2 & 2.2 \\
\hline & Min & 77.7 & 6.6 & 77.6 & 6.4 & 76.9 & 5.2 & 78.0 & 5.6 & 76.9 & 5.2 \\
\hline & Max & 93.4 & 22.3 & 93.6 & 22.4 & 94.8 & 23.1 & 94.4 & 22.0 & 94.8 & 23.1 \\
\hline
\end{tabular}

\section{REFERENCES}

[1] Bodrova, E., \& Leong, D.J. (1996). Tools of mind: The Vygolskian approach to early Childhood Education. Englewood Cliffs, NJ: Merrill/Prenlice Hall.

[2] Bransford, J., Brown, A., \& Cocking, R. (2000). How People Learn: Brain, Mind, and Experience \& School. Washington, DC: National Academy Press.

[3] Chang, K., Chen, I., \& Sung, Y. (2002). The effect of concept mapping to enhance text comprehension and summarization. The Journal of Experimental Education 71(1), 5-23.

[4] Elkonin, D.B. (19 71). Development of Speech. In A. V. Zaporozhets \& D. B Elkonin (Eds.), The psychology of preschool children. (Pages 111- 185). Cambridge, MA: MID Press.

[5] Galperin, P. (1985). Instructional methods and cognitive development in childhood. Moscow: Pedagogika.

[6] Cazden, C.B. (1983). Adult assistance to language development: Scaffolds, models, and direct instruction. In R. P. Parker \& F. A. Davis (Eds.), Developing literacy: Young children's use of language (pp. 3-17). Newark, DE: International Reading Association.

[7] Hartman, H. (2002). Scaffolding \& cooperative learning. Human learning and instruction (pp. 23-69). New York: University of New York.

[8] Hatch, E., \& Brown, C. (1995). Vocabulary, semantics, and language education. Cambridge University Press: Cambridge.

[9] Hyland, K. (2003). Tasks in L2 writing class. In Jack C. Richards (Ed.), Second language writing (pp. 112-141). New York: Cambridge University Press. 
[10] Larkin, M. (2002). Using scaffolded instruction to optimize learning. Retrieved January 10,2013 from www.vtaide.com/png/ERIC/Scaffolding.htm.

[11] Lieb, M, M. (2006). Vocabulary acquisition and expansion for the EFL learner. In B. A. Jones (Ed.). The Proceedings of Teachers Helping Teachers: Seminar on Teaching Strategies for the ESL Classroom. College of Foreign Languages, Hue University, Vietnam, March 25-30, 2006, p.84-89.

[12] McCarthy, E. M. (1992). Anatomy of a teaching interaction: The components of teaching in the ZPD. Paper presented at the annual meeting of the American Educational Research Association. San Francisco: CA.

[13] Nation, P. (2003). Learning vocabulary in another language: a test of teacher's knowledge. Retrieved December 24, 2012 from http://www.vuw.ac.nz./lals/staff/paul-nation/vocrefs/testa.aspx.

[14] Nation, I. S. P., \& Beglar, D. (2007). A vocabulary size test. The Language Teacher, 31(7), 9-13.

[15] Olson, J., \& Platt, J. (2000). The instructional cycle. Teaching children and adolescents with Special Needs (pp. 170-197). Upper Saddle River, NJ: Prentice-Hall, Inc.

[16] Raymond, E. (2000). Cognitive characteristics. Learners with Mild Disabilities (pp. 169-201). Needham Heights, MA: Allyn \& Bacon, A Pearson Education Company.

[17] Venger, L. A. (1986). Development of cognitive abilities through pre-school education. Moscow: Pedagogika.

[18] Vygotsky, L. (1978). The development of higher psychological processes. Mind in society. Cambridge, MA: Harvard University Press.

[19] Wood, D., Bruner, J., \& Ross, G. (1976). The role of tutoring in problem solving. Journal of Child Psychology and Psychiatry, $17,89-100$

Mansoor Fahim is an Associate Professor in TEFL. He is a faculty member at Allameh Tabatabaie University. He has carried out a number of researches, compiled and translated a couple of books and taken part in a number of conferences and Seminars nationally and internationally.

Bahareh Jouybar is an M.A. graduate student in TEFL from South Tehran Branch of Islamic Azad University. She has recently finished her M.A. studies at the above mentioned university. She has been teaching English for about 8 years in qualified English institutes in Tehran, Iran. 